Reprinted with permission from: Weed Science. July/Sept 1996. Vol. 44 (3):629-633.

Published and copyrighted by: Weed Science Society of America. http://www.wssa.net

\title{
Leafy spurge (Euphorbia esula) genotype affects gall midge (Spurgia esulae) establishment $^{1}$
}

RODNEY G. LYM, SCOTT J. NISSEN, MARTHA L. ROWE, DONALD J. LEE, and ROBERT A. MASTERS

Prof., Plant Sciences Dep., North Dakota State University, Fargo, ND 58105-5051; Asst. Prof.; Res. Assoc., Assoc. Prof. Dep. Agron., and Rangeland Sci., U.S. Dep. Agric., Agric Res. Ser., Univ. Nebraska, Lincoln, NE 68583-0915. Current address of S. J. Nissen, Department of Plant Pathology and Weed Science, Colorado State University, Fort Collins, CO 80523-1174.

\begin{abstract}
:
Greenhouse cage studies were conducted to determine the influence of shoot morphology and genetic variation on establishment of Spurgia esulae gall midge on seven leafy spurge genotypes. The genotypes were collected from South Dakota, North Dakota, Nebraska, Montana, Wyoming, Manitoba, and Austria. Genotypes from South Dakota and Nebraska were most susceptible to gall formation and had the highest larvae survival, while the genotypes from Montana and Manitoba were most resistant. Morphological characteristics of the leafy spurge stem tips, such as stem diameter, leaf length, width, and area did not correlate with gall formation or larvae survival. Chloroplast DNA restriction fragment length polymorphism analysis of the genotypes identified six chloroplast types among the seven leafy spurge genotypes. The two genotypes most resistant to galling by $S$. esulae, Manitoba and Montana, had the same chloroplast genotype, but also were closely related to the two most susceptible genotypes. Because eggs were laid on all genotypes, it appears that adult females were not preferentially selecting appropriate host genotypes, but that egg and larvae survival was strongly influenced by genotype.
\end{abstract}

\section{Nomenclature:}

Leafy spurge gall midge, Spurgia esulae Gagné; leafy spurge, Euphorbia esula L. $\#^{2}$ EPHES.

\footnotetext{
${ }^{1}$ Received for publication September 6, 1995, and in revised form December 3,1995.

${ }^{2}$ Letters following this symbol are a WSSA-approved computer code from Composite List of Weeds, Revised 1989. Available from WSSA. 1508 West University Ave., Champaign, IL 61821-3133.
} 


\section{Additional index words:}

Biological control, rangeland weed control, cpDNA, RFLP, genetic markers, EPHES.

\section{Introduction}

Interest in biological weed control has increased with public concerns about environmental impacts associated with chemical weed control and potential reductions in species diversity because of limited herbicide selectivity. Proponents suggest that biological weed control, once established, could be more economical than chemical weed control because it is self-sustaining (7). Biological control efforts are often directed toward vast weed infestations on lands that are not intensively managed such as rangeland or other less disturbed natural habitats where the low monetary return per hectare severely limits the economics of weed management.

Biological weed control has been practiced for the last $200 \mathrm{yr}$ and there have been some highly successful biocontrol programs. Cactus (Opuntia spp.) control in Australia and India and St. Johnswort (Hypericum perforatum L.) control in the Pacific Northwest are commonly cited examples. However, near-complete weed control with biological agents has been achieved in only $25 \%$ of the attempts world-wide (19).

The reasons for the variable nature of biological weed control has been debated but not explained. One important factor could be the genetic diversity in the target weed species $(1,3,19)$. Using mode of reproduction as an indicator of the relative amount of genetic diversity within a species, Burdon and Marshall (3) concluded that plant species reproducing primarily by asexual means were more likely to be controlled with biological agents than species reproducing sexually. Therefore, understanding the genetic diversity of a species could be a critical step in establishing a successful biological control program.

Attempts have been made to determine genetic variation in some weed species targeted for biological weed control in North America $(13,14)$. The genetic diversity and population structure of exotic North American genotypes compared to native Eurasian populations probably are characterized better in leafy spurge than any other weed. Leafy spurge is an introduced weed of rangeland and pastures of the Northern Great Plains where it displaces nearly all other species (2). Leafy spurge is very difficult to control chemically because it has an extensive root system capable of shoot regeneration from adventitious buds on the crown and roots. These characteristics make leafy spurge a good target for biological control. A major program of biological control was initiated against leafy spurge in the 1980s. The stem-boring weevil Oberea erythrocephala (Shrank.) (Coleoptera; Cerambycidae) was introduced in North Dakota in 1985 and was the first leafy spurge biocontrol insect to become established in the state (10). The leafy spurge gall midge was introduced from Europe in 1986 and began to increase in population much faster than $O$. erythrocephala. The leafy spurge gall midge controls leafy spurge by preventing galled stems from flowering, thereby decreasing seed production (17). The

Page 2 of 10 
female adult lays eggs on the main growing tip, which is often killed by the feeding larvae, and secondary shoots are then produced $(11,17)$. The secondary shoots are attacked by subsequent generations. This species has the potential to be a very beneficial biocontrol agent against leafy spurge by limiting one of the major means for distribution over long distances.

Field observations suggested that the gall midge was not able to establish galls on all leafy spurge plants present at some release sites (11). This failure may be due to resistance to galling in some leafy spurge genotypes. Several genotypes of leafy spurge have been identified based on differences in phytochemical markers $(5,9)$. Analysis using $\mathrm{cpDNA}^{3}$ RFLP of North American leafy spurge has indicated that populations consist of multiple genotypes (14). The purpose of this research was to determine if variation in gall formation on leafy spurge was associated with morphological characteristics of the shoot apex or genetic variation as determined by cpDNA RFLP analysis.

\section{Materials and methods}

Plant material. Seven leafy spurge genotypes were propagated from stem tip cuttings and grown using optimum greenhouse conditions and growth techniques (8). The genotypes included were: 78AS001 ${ }^{4}$ from Austria; 79MB001 from Manitoba, Canada; and 80MT002, 79NE003, 84ND001, 80SD001, and 80WY001 from Montana, Nebraska, North Dakota, South Dakota, and Wyoming, respectively. The plants were selected based on differences in vegetation and reproductive characteristics from geographically separated populations. Cuttings were planted $4 \mathrm{~cm}$ deep in a $4-\mathrm{cm}$-diam by $20-\mathrm{cm}$-long conical pot ${ }^{5}$, and grown at $27^{\circ} \mathrm{C}$ with a 16-hour photoperiod in a peat, perlite, and vermiculite growth medium ${ }^{6}$ at $\mathrm{pH}$ 7. The plants were fertilized with a commercial mixture of 15-30$15(\mathrm{~N}, \mathrm{P}, \mathrm{K})$ at $270 \mathrm{~kg} \mathrm{~N} \mathrm{ha}^{-1}$ when 20 days old and weekly thereafter. Plants were watered as needed.

Host selection and establishment. Leafy spurge genotypes were grown as described for 6 weeks, then cut back to the soil surface and allowed to regrow to approximately 15 $\mathrm{cm}$. The plants were then placed in clear plexiglass cages $150-\mathrm{cm}-$ long by $60-\mathrm{cm}$-wide and 60-cm-high.

Stems bearing galls containing larvae and pupae were collected from insectaries near Valley City or Fargo, ND, and placed as bouquets in beakers of water within the plexiglass cages. Adults were allowed to emerge from the galls as they would in the field. The adult life span is approximately 48 hours, so most eggs were deposited within a 7-day period from first to last adult emergence. The galls formed on each leafy spurge genotype

\footnotetext{
${ }^{3}$ Abbreviations: cpDNA, chloroplast DNA; RFLP, restriction fragment length polymorphism, GS, genetic similarity-, and PCA, principal component analysis.

${ }^{4}$ Registry of leafy spurge accensions maintained by David G. Davis, USDA Biosciences Res. Lab., Fargo. ND 58105. Identification sequence is year collected, U.S. postal code for state, province, or country, and order of registration.

${ }^{5}$ Cone-tainer Nursery, Canby, OR 97013.

${ }^{6}$ Sunshine Mix No. 1, Patented formulation with wetting agents. Fisons Western Corp. Downers Grove. IL 60515.
} 
were counted approximately 3 weeks after the majority of adults had emerged. Galls were then dissected to determine the number of larvae per gall.

Plants of each genotype were arranged in a randomized complete block design within the cage with six blocks per run for the host selection and establishment experiments. The experiment was repeated three times each in 1992 and 1993 from mid May to late July. The two data sets, percent galling and larvae per gall had similar variance among runs so data from runs were combined and subjected to analysis of variance and mean separation using a protected LSD test at $\mathrm{p}=0.05$.

Genotype characterization. Plants were grown as previously described, and the morphological characteristics of the stem tips where gall midge eggs are laid were determined. An electronic caliper was used to measure the stem diameter about $1 \mathrm{~cm}$ below the stem tip. Leaf length, width, and area were determined using the caliper for the five leaves closest to the tip of each plant. Leaf length was measured from the base to the tip at the longest part and width from the widest part of each leaf. Leaf area was determined three times per leaf with an area meter ${ }^{7}$ and the mean value was used for analysis. There were 10 plants per genotype and the experiment was repeated three times. Data were analyzed using correlation and stepwise regression procedures (21) to determine the relationship of leaf and stem morphological characteristics to the number of galls per plant and larvae per gall.

Genotype characterization. Total genomic DNA was extracted from freeze-dried leaf tissue of the seven leafy spurge genotypes using the CTAB buffer and chloroform/octanol extraction procedure of Saghai-Maroof (18). DNA concentrations were determined by fluorometer using DNA-specific dye Hoechst 33258. A survey of cpDNA RFLPs, was conducted by digesting genomic DNA with 12 restriction enzymes: BamHI, BclI, CfoI, ClaI, EcoRI, EcoRV, HindIII, HinfI, HpaII, KpnI, XbaI, and XhoI. Agarose/Synergel $(0.5$ and $0.25 \% \mathrm{w} / \mathrm{v})$ gels were loaded with $5 \mu \mathrm{g}$ of digested DNA per lane and electrophoresed for $23 \mathrm{~h}$ at 25 volts. DNA was blotted onto Hybond N (Amersham) nylon membranes by neutral Southern transfer (20). After transfer, DNA was ultraviolet crosslinked to the nylon membrane at $120,000 \mathrm{~mJ}$, then baked at $60 \mathrm{C}$ overnight.

Six mung bean (Phaseolus aureus L.) cpDNA PstI and SalI restriction fragments, cloned into the plasmid vector pBR322, were used as hybridization probes in this study $(15,16)$. Previous research has shown that mung bean cpDNA probes hybridize well to membrane bound leafy spurge cpDNA (13). Mung bean cpDNA probes were labelled with digoxigenin-11-2'-deoxyuridine-5'-triphosphate by random priming (6). RFLPs were detected with a commercial kit using Lumiphos $530^{8}$ as substrate for antidigoxigeninconjugated alkaline phosphatase, and varying exposures to XAR-5 X-ray film ${ }^{9}$.

The RFLP data set consisted of the presence or absence of bands that were used to determine relatedness among the seven genotypes. These bands were treated as characters. Genotypes that shared the most characters were thought to have the closest relationship.

\footnotetext{
${ }^{7}$ Model LI-3050A, LI-COR Inc., Lincoln. NE 68504.

${ }^{8}$ Boehringer-Mannheim Corporation, Indianapolis, IN 46250-0414.

${ }^{9}$ Eastman-Kodak Company. Rochester, NY 14650.
} 
Relatedness between any two genotypes was calculated using $\mathrm{GS}^{4}$, a measure devised by Dice (4) and first suggested for RFLP data by Nei and Li (12).

\section{Results and discussion}

The number of galls established varied by plant genotype (Table 1). The number of stem tips galled ranged from an average of $80 \%$ on the genotypes from Nebraska and South Dakota to only $8 \%$ on the genotype from Montana. The Austrian genotype was intermediate in susceptibility to galling. This genotype is from the native range of the gall midge but had fewer galls than genotypes from South Dakota and Nebraska.

The number of larvae per gall followed the same trend as the number of galls produced, with the genotypes from Nebraska and South Dakota having the highest average number of larvae per gall (Table 1). There were an average of only 13 larvae/gall for the Austrian genotype and only 1 larvae per 2 galls for the Manitoba genotype. No larvae were ever collected from galls on the genotype from Montana throughout the 2-yr experiment.

The overall effectiveness of the gall midge in reducing leafy spurge infestations depends on the ability of the biocontrol agent to select an appropriate host plant to form galls and survival of the larvae within the galls. A susceptibility index [(percent tips galled per plant) $\mathrm{x}$ (no. larvae per gall)] was used to estimate the susceptibility of a genotype. Based on this index, the genotypes from Nebraska and South Dakota were susceptible, Manitoba and Montana were resistant, and the remaining three genotypes were intermediate (Table 1).

It was hypothesized that gall midge adults were selecting appropriate host genotypes based on stem-tip morphological characteristics. Stem tip diameter, leaf shape, and leaf area varied by leafy spurge genotype (Table 2). Stem diameter was the same for the genotypes from Montana, Nebraska, and South Dakota. However, the greatest number of galls and larvae per gall were found on the Nebraska and South Dakota genotypes, while the genotype from Montana had the fewest (Table 1).

Table 1. Effect of leafy spurge genotype on gall formation induced by Spurgia esulae larvae $^{a}$.

\begin{tabular}{|c|c|c|c|c|}
\hline \multicolumn{2}{|c|}{ Leafy spurge } & \multirow[b]{2}{*}{ Tips galled } & \multirow[b]{2}{*}{ Larvae/gall } & \multirow[b]{2}{*}{ Susceptibility index ${ }^{c}$} \\
\hline Location & Genotype code ${ }^{b}$ & & & \\
\hline & & $\%$ & No. & \\
\hline Austria & 78AS001 & 44 & 13 & 572 \\
\hline Manitoba & 79MB001 & 32 & 0.5 & 16 \\
\hline Montana & 80MT002 & 8 & 0 & 0 \\
\hline Nebraska & 79NE003 & 76 & 42 & 3192 \\
\hline North Dakota & 84ND001 & 29 & 5 & 145 \\
\hline South Dakota & 80SD001 & 83 & 56 & 4648 \\
\hline Wyoming & 80WY001 & 56 & 14 & 784 \\
\hline $\operatorname{LSD}(0.05)$ & & 30 & 27 & \\
\hline
\end{tabular}

${ }^{\mathrm{a}}$ Mean of 6 runs.

${ }^{\mathrm{b}}$ Identification sequence is year collected; U.S. postal code for state, province, or country; and order of registration.

${ }^{\mathrm{c}}$ Susceptibility index $=($ tips galled $) \times($ larvae $/$ gall $)$. 
Gall formation was not related to leaf length as the genotype from Nebraska had the longest stem tip leaves while the South Dakota genotype had among the shortest (Table 2) even though both were classified as susceptible (Table 1). The Nebraska genotype had longer leaves than the Montana or South Dakota genotypes, while the Montana genotype had wider leaves than the Nebraska and South Dakota genotype. Leaf area was greatest for the Montana and Manitoba genotypes, intermediate for the Nebraska and South Dakota genotypes, and lowest for the Austrian and Wyoming genotypes. There was no clear trend or correlation between morphological characteristics and gall midge host selection or establishment (data not shown).

Table 2. Morphological characteristics of leafy spurge genotypes grown under optimum greenhouse conditions ${ }^{\mathrm{a}}$ in the vegetative growth stage.

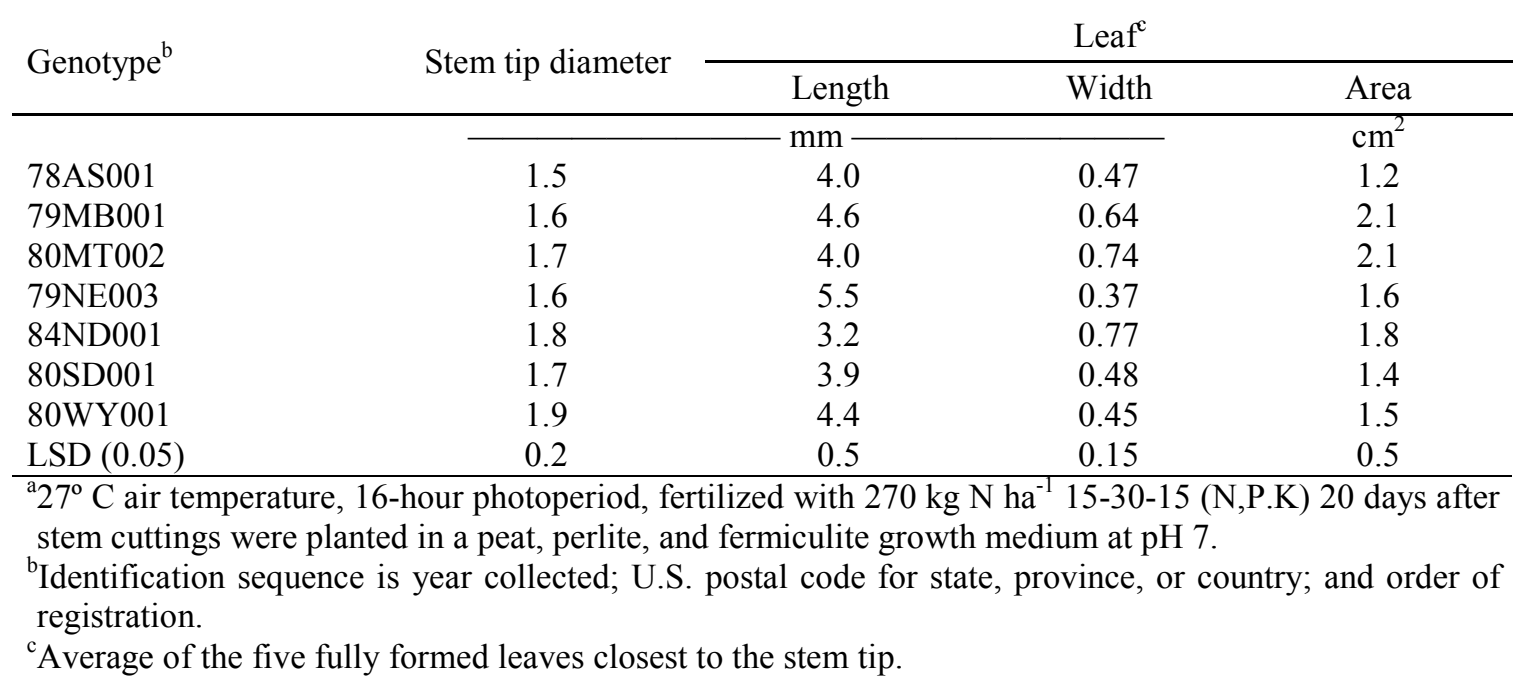

Close examination of egg deposition indicated that because of high adult populations in each cage, eggs were being deposited on at least one stem of each genotype. A complementary experiment was conducted in which bouquets of $S$. esulae galls were placed in separate cages containing plants of the genotypes from Nebraska (highly susceptible) or Montana (not susceptible). Galls bearing larvae were produced on nearly every tip of the Nebraska plants (data not shown); however, no viable galls were produced on the Montana genotype even though eggs had been deposited on every stem tip ( $>50$ tips total). These observations suggest that the adult females do not preferentially select appropriate host genotypes for egg laying but egg development and larvae survival were strongly influenced by genotype.

CpDNA RFLP analyses was conducted to determine whether genetic variation among genotypes was present and would correlate to host selection or larvae survival. The combination of 12 restriction enzymes and six mung bean cpDNA probes generated a total of 124 cpDNA fragments (bands); 62 of these fragments were polymorphic. Six cpDNA genotypes were represented among the seven leafy spurge genotypes (Tables 3 and 4). The Montana and Manitoba genotypes had identical fragment patterns. 
Previous research estimated the genetic diversity and population structure of the North American leafy spurge infestation (14) based on cpDNA RFLP analysis using three restriction enzymes. We compared this larger survey information to the seven leafy spurge genotypes used in the present study by $\mathrm{PCA}^{3}$ (Figure 1). This comparison was based on a smaller data set generated with three restriction enzymes (EcoRI, HindIII, EcoRV) combined with the same cpDNA probes. GS values were used for PCA to compare the seven leafy spurge genotypes to $14 \mathrm{cpDNA}$ genotypes identified in the previous survey. CpDNA genotypes from the seven leafy spurge genotypes appeared to be a good representation of the variation found among the other North American cpDNA genotypes.

Table 3. Number of band differences (polymorphic fragments) between leafy spurge genotypes used in $S$. esulae host selection and establishment experiments.

\begin{tabular}{lccccccc}
\hline Genotype & Austrian & Manitoba & Montana & Nebraska & $\begin{array}{c}\text { North } \\
\text { Dakota }\end{array}$ & $\begin{array}{c}\text { South } \\
\text { Dakota }\end{array}$ & Wyoming \\
\hline Austrian & 0 & & & & & & \\
Manitoba & 46 & 0 & & & & & \\
Montana & 46 & 0 & 0 & & & & \\
Nebraska & 45 & 13 & 13 & 0 & & & \\
North Dakota & 34 & 28 & 28 & 27 & 0 & & \\
South Dakota & 45 & 7 & 7 & 13 & 25 & 0 & 0 \\
Wyoming & 27 & 23 & 23 & 22 & 9 & 20 & 0 \\
\hline
\end{tabular}

Among the seven leafy spurge genotypes examined in this work, the North American genotypes were quite different from the Austrian genotype and more closely related to each other based on the number of band differences and GS values (Tables 3 and 4). However, the magnitude of the GS values for cpDNAs was not a predictor of gall midge response. Although the two most resistant plants, Montana and Manitoba, had identical cpDNA genotypes, the next most closely related in terms of GS and band differences were Nebraska and South Dakota, the most susceptible plants tested. A plot of the first two principal components of PCA, accounting for $77 \%$ of the variation among types,

Table 4. Genetic similarities $\left(G^{2}\right)$ between leafy spurge genotypes used in $S$. esulae host selection and establishment experiments.

\begin{tabular}{|c|c|c|c|c|c|c|c|}
\hline Genotype & Austrian & Manitoba & Montana & Nebraska & $\begin{array}{l}\text { North } \\
\text { Dakota }\end{array}$ & $\begin{array}{l}\text { South } \\
\text { Dakota }\end{array}$ & Wyoming \\
\hline Austrian & 1.000 & & & & & & \\
\hline Manitoba & 0.849 & 1.000 & & & & & \\
\hline Montana & 0.849 & 1.000 & 1.000 & & & & \\
\hline Nebraska & 0.851 & 0.957 & 0.957 & 1.000 & & & \\
\hline North Dakota & 0.889 & 0.908 & 0.908 & 0.918 & 1.000 & & \\
\hline South Dakota & 0.851 & 0.977 & 0.977 & 0.967 & 0.918 & 1.000 & \\
\hline Wyoming & 0.911 & 0.924 & 0.924 & 0.927 & 0.970 & 0.934 & 1.000 \\
\hline
\end{tabular}


placed the Nebraska and South Dakota cpDNA genotypes closest to each other (Figure 2). However, other measures of relatedness such as band differences (Table 3) and genetic similarity (Table 4) indicated a greater degree of relatedness between South Dakota cpDNA and the Montana/Manitoba genotypes. The genotypes of intermediate susceptibility to the gall midge, Austria, Wyoming, and North Dakota, were less closely related to the extreme genotypes, and generally to each other.

Biocontrol agent-weed compatibility is a very complex relationship involving genetic expression of weed species and biocontrol agents combined with environmental influences (7). The genes controlling the biochemical or physiological basis of differential response to the gall midge are not expected to be encoded by the chloroplast genome. However, the chloroplast genome would tend to maintain its association with populations of leafy spurge to which this insect was adapted. The maintenance of this association over time depends upon a number of factors including the selection pressure imposed by the insect and the mixing of compatible and incompatible populations from migration and multiple introductions into North America.

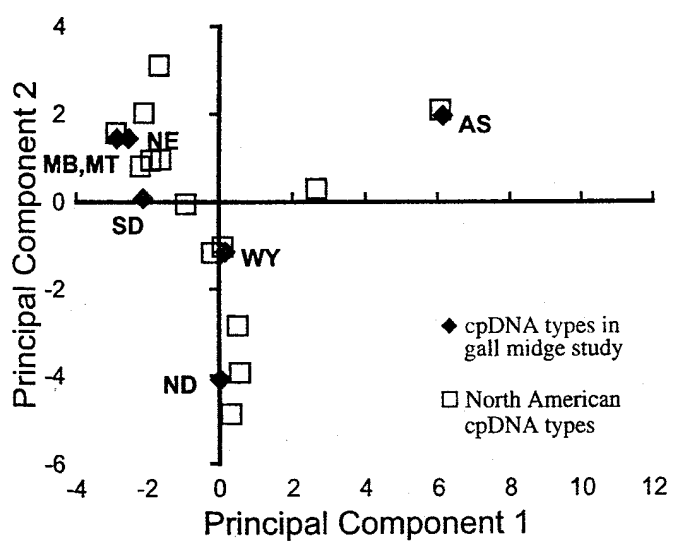

Figure 1. Principal component analysis showing the relationship between the seven leafy spurge genotypes used in the present study and 14 chloroplast DNA genotypes characterized in a previous survey (13).

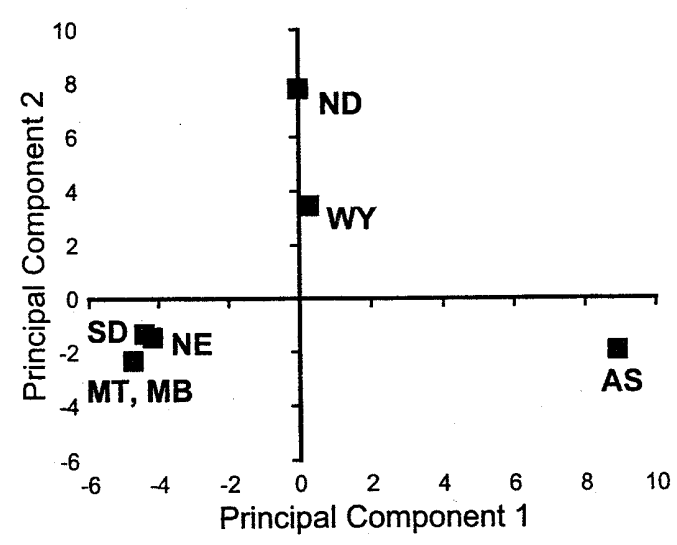

Figure 2. Principal component analysis of the seven leafy spurge genotypes. PCA was based on genetic similarities (GS) and was calculated based on the 62 polymorphic fragments generated with 12 RFLPs and six mung bean chloroplast DNA probes.

This research represents the first step in empirical evaluation of the role that plant genetic variation plays in the potential success of a biocontrol agent. The cpDNA genotype will be a useful predictor of a leafy spurge plant's genetic predisposition to gall midge attack if it is matched with an identical or nearly identical cpDNA genotype previously characterized as to susceptibility. Early identification will help land managers target specific biocontrol agents to the most susceptible weed genotypes. This specific approach to weed biocontrol should increase the success of biocontrol programs and save time and money for land managers. 


\section{Acknowledgments}

The authors thank Jim Kapaun, former weed science technician of North Dakota State University for technical assistance and helpful suggestions. This work was funded in part by USDA-APHIS. CpDNA RFLP analysis of leafy spurge genotypes was made possible by funds provided by USDA-CSRS Rangeland Research Grant \#93-98300-8729.

\section{Literature cited}

1. Barrett, S.C.B. 1982. Genetic variation in weeds. Pages 73-98 in R. Charudattan and H. L. Walker. eds. Biological Control of Weeds With Plant Pathogens, John Wiley and Sons, New York.

2. Belcher, J. W. and S. D. Wilson. 1989. Leafy spurge and the species composition of a mixed-grass prairie. J. Range Manage. 42:172-175.

3. Burdon, J. J. and D. R. Marshall. 1981. Biological control and the reproductive mode of weeds. J. Appl. Ecol. 18:649-658.

4. Dice, L. R. 1945. Measurements of the amount of ecologic association between species. Ecol. 26:297302.

5. Evans, J. O., J. M. Torell, R. V. Valcaru, and G. G. Smith. 199 1. Analytical pyrolysis-pattern recognition for the characterization of leafy spurge (Euphorbia esula) biotypes. Ann. Applied Bio. 119:47-58.

6. Feinberg, A. P. and B. Vogelstein. 1983. A technique for radio labelling DNA restriction endonuclease fragments with high specific activity. Anal. Biochem. 132:6-13.

7. Huffaker, C. B. 1974. Fundamentals of biological weed control. Pages 631-649 in P. DeBach, ed. Biological Control of Insects, Pests and Weeds. Chapman and Hall Limited. London.

8. Lym, R. G. 1992. Propagation of Euphorbia esula for leafy spurge biocontrol agents. Weed Sci. 40:326-332.

9. Manners, G. D. and D. G. Davis. 1984. Epicuticular wax constituents of North American and European Euphorbia esula biotypes. Phytochem. 23:1059-1062.

10. Messersmith, C. G. and R. G. Lym. 1990. Leafy spurge control: 10 years of research enhancement. North Dakota Farm Res. 47(6):3-6.

11. Nelson, J. 1994. The gall midge Spurgia esulae, on leafy spurge. M.S. thesis, North Dakota State University, Fargo, ND, 58105.

12. Nei, M. and W. Li. 1979. Mathematical model for studying genetic variation in terms of restriction endonucleases. Proc. Natl. Acad. Sci. 76:5269-5273.

13. Nissen, S. J., R. A. Masters, D. J. Lee, and M. L. Rowe. 1992. Comparisons of restriction fragment length polymorphisms in chloroplast DNA of five leafy spurge (Euphorbia spp.) accessions. Weed Sci. 40:63-67.

14. Nissen, S. J., R. A. Masters, D. J. Lee, and M. L. Rowe. 1995. DNA based marker systems to determine genetic diversity of weedy species and their application to biocontrol. Weed Sci. 43:504-513.

15. Palmer. J. D., B. Osorio, and W. F Thompson. 1988. Evolutionary significance of inversions in legume chloroplast DNAs. Current Genetics 14:65-74.

16. Palmer, J. D. and W. F. Thompson. 1981. Clone banks for mung bean, pea and spinach chloroplast genomes. Gene 15:21-26.

17. Pecora, P., R. W. Pemberton. M. Stazi, and G. R. Johnson. 1991. Host specificity of Spurgia esulae Gagné (Diptera: Cecidomyiidae), a gall midge introduced into the United States for control of leafy spurge (Euphorbia esula L. “complex"). Environ. Entomol. 20:282-287.

Page 9 of 10 
18. Saghai-Maroof, M. A., K. M. Solimam. R. A. Jorgensen, and R. W. Allard. 1984. Ribosomal DNA spacer-length polymorphisms in barley: Mendelian inheritance, chromosomal location, and population dynamics. Proc. Nat. Acad. Sci. 81:8014-8018.

19. Sheppard, A. W. 1992. Predicting biological weed control. Trends Ecol. Evol. 7:290-290.

20. Southern, E. M. 1975. Detection of specific sequences among DNA fragments separated by gel electrophoresis. J. Mol. Biol. 98:503-517.

21. Statistical Analysis System Institute. 1990. SAS/STAT User's Guide. Cary, NC 27512. 